of the Senate and Council. To the deliberations of these bodies he brought penetrating criticism, sometimes caustic, but always valuable. He will be much missed by students and staff alike.

\section{Linnean Society of London: Anniversary Meeting}

$A T$ the anniversary meeting of the Linnean Society of London held on May 28, the Linnean Gold Medal was awarded to Prof. P. A. Buxton. The following were elected officers for the session 1953-54: President: Lieut.-Colonel R. B. Seymour Sewell; Treasurer: Colonel F. C. Stern; Secretaries : (Zoology) Dr. A. Tindell Hopwood, (Botany) Dr. George Taylor; New Members of Council: Mr. J. S. L. Gilmour, Prof. C. T. Ingold, Dr. L. Harrison Matthews, Dr. C. R. Metcalfe and Prof. E. Smith. Prof. Albert Dalcq, of Brussels, Prof. Alfred Sherwood Romer, of Boston, Mass., and Prof. Roger-Jean Heim, of Paris, were elected foreign members; and Robert Mackechnie and Douglas Miller Reid were elected associates honoris causa.

\section{Bibliography of Scientific Aspects of Atomic Energy}

THE two volumes of "An International Bibliography on Atomic Energy", published by the United Nations Atomic Energy Section of the Department of Security Council Affairs, deal respectively with political, economic and social aspects, and with scientific aspects. Vol. I was issued in 1949 and Supplement No. 1 to this volume in 1950 (see Nature, 167, 671; 1951). In 1948 and 1949 , preliminary mimeographed editions of the component parts of Vol. 2 were issued and circulated among experts of various countries, and in 1951 the printed edition was published. This volume, which listed more than twenty-four thousand articles, books and pamphlets published in all parts of the world during 1925-49, is divided into five main sections : fundamental nuclear science; the physics and engineering of nuclear reactors; the biological and medical effects of high-energy radiations ; isotopes in biology and medicine; and applications of radioactive tracers in non-biological sciences and technology. However, the flow of scientific papers on nuclear energy has continued unabated, and periodical supplements to Vol. 2 have accordingly been planned, the first of which has recently been published (pp. 326. New York: U.N. Atomic Energy Section, Department of Security Council Affairs; London: H.M.S.O., 1952. 3.25 dollars, 25s. or 14 Swiss francs). The five sections into which it is divided are the same as in the original volume; but the table of contents has been somewhat improved in accordance with suggestions received, and fresh sub-divisions have been introduced to take account of rapidly growing or new research topics. The contents consist of 8,231 items, each item containing the authors' names, the title of the article (with translation if the original is in Russian), abbreviated title of the journal, the volume and page numbers and the date, and two appendixes (one an author index and the other a list of the journals, with addresses, arranged alphabetically under the abbreviations used in the volume). The bibliography does not exclude reviews and general articles, and in this respect is superior to some abstracting journals ; but the absence of translations of titles in foreign languages other than Russian will cause difficulty to many users and will hinder further reference to abstracts in abstracting journals.

\section{Institution of Professional Civil Servants}

IN his presidential address to the Institution of Professional Civil Servants at the annual delegate conference on May 18, Sir Richard Redmayne commented at some length on the position of the Department of Scientific and Industrial Research as indicated by that Department's recent annual report. The current estimates of the Department, he said, represent not a slight increase on the estimates for 1950-51, but a reduction of about ten per cent, and he urged that reductions in expenditure involving restriction of important and necessary work are not economy but waste. Sir Richard also referred to the Institution's intervention in the decision of the Ministry of Works to dismiss certain artist-craftsmen employed on the restoration of national art treasures, and the reversal of the decision after debate in the House of Lords. The annual report of the Institution's executive committee indicates its intention of seeking to improve the efficiency of the Civil Service by ensuring not only the proper employment of professional, scientific and technical officers, but also their full access to administrative posts on the bases envisaged in the Gardiner Committees' reports. It is also proposed to press (1) the claims for parity between the experimental and the scientific officer classes on one hand and the executive and administrative classes on the other; (ii) the technical grades salary claim deriving from the Gardiner report on the Works Group; and (iii) the salary scales for medical officers based on the Spens reports and the judgment of Mr. Justice Danckwerts.

\section{Pacific Science Council Secretariat: Report for $1951-52$}

A Report on the work of the Pacific Science Council Secretariat, covering the period March 1951December 1952 (Bulletin PS/52/9; pp. 28 ; from the B. P. Bishop Museum, Honolulu, 1952), lists the continuing and completed projects of the secretariat, the supplements to the Information Bulletin issued during 1951 and 1952, and of the standing committees of the Pacific Science Association. The executive secretary represented the secretariat at the Australian National University's jubilee seminar on "Social Processes in the Pacific", and afterwards visited Singapore, Java, New Caledonia and Fiji. Reference is made to the value of the secretariat's assistance programme for transient scientific workers. The monthly summary, due for release in midJanuary 1953, completed one full year of operation of the Pacific Area Communicable Disease Information Service; plague, small-pox, epidemic typhus, cholera, yellow fever, relapsing fever, all of which have already been reported by cable on a world-wide basis by the United Nations World Health Organization, are omitted to avoid duplication. The summary covers the reported incidence of more than thirty other diseases selected on the advice of health officers in the Pacific. A Periodicals Exchange Centre, covering periodicals published between 1920 and 1945 , has been established by the secretariat jointly with the Unesco Science Co-operation Offices for South East Asia and for East Asia. The publication of a survey of Pacific scientific expeditions and of a handbook on organizations engaged in scientific research on an international scale in the Pacific was under investigation, while the secretariat was also responsible for organizing the Hawaii symposium on scientific research in the Pacific (held during March 9-10, 